\title{
THE PATH TO WHICH WILD ERROR LEADS: A LUCRETIAN COMEDY OF ERRORS
}

\author{
Eric Langley
}

\begin{abstract}
Had not Epicurus, and his Follower Lucretius, very well known that [free will] was a thing which every one could not but experience in Himself, he had certainly ... followed his Old Master Democritus, and asserted the Mind of Man to be as necessarily and fatally moved by the strokes of his Atoms, [but he was] forced to desert, and to assert the Liberty of the Soul of Man; and 'twas to make this out according to his Senseless Hypothesis, that he Invented that Unaccountable Oblique Motion of his Atoms; which Lucretius calls Exiguum Clinamen Principiorum. ${ }^{1}$
\end{abstract}

While extricating the dedicatory epigraph for his Venus and Adonis from Ovid's Amores I. xv lines thirty-eight to nine ('let boors like dross; to me may Phoebus bring / His goblets filled from the Castalian spring'), Shakespeare's eye is caught by lines twenty-six to seven: 'Sublime Lucretius' verses shall not die | Till one day ends the world in tragedy'. ${ }^{2}$ While checking his copy of Thomas Cooper's 1578 Thesaurus lingua Romanae \& Britannicae, Shakespeare comes across the following entry:

Clinâmen pen. prod. clinâminis, n.g. Lucret. A declining or bowing. ${ }^{3}$

While reading Harold Bloom's 1973 The Anxiety of Influence, Shakespeare is amused to read: 'what is Poetic Influence anyway? Can the study of it really be anything more than the wearisome industry of source-hunting, of allusion-counting? ... perhaps there are only more or less creative or interesting mis-readings, for is not every reading necessarily a clinamen? ${ }^{34}$

Celebrating the poetic misprision - the 'act of creative correction that is actually and necessarily a misinterpretation [and a] distortion' inherent in one poet's appropriation of, or interaction with

It is perhaps always the case that in our intellectual lives we happen upon people, books, and ideas simply by chance that end up influencing our thinking for the rest of our lives.

Leland Monk, Standard Deviations (Stanford: Stanford UP, 1993), ackowledgements

With thanks to Julia Jordan who introduced me to the clinamen, and Alex Davis who encouraged my trajectory.

${ }^{1}$ John Harris, A Refutation of the Atheistical Notion of Fate (London: by J. L., 1698), 19.

${ }^{2}$ Ovid, The Love Poems, trans. A. D. Melville (Oxford, 1990).

3 Thomas Cooper, Thesaurus lingua Romanae \& Britannicae (London: by Henry Denham, 1578).

${ }^{4}$ Harold Bloom, The Anxiety of Influence: A Theory of Poetry, $2^{\text {nd }}$ ed. (OUP, 1997), 31; 43. 
another - Bloom advocates 'the quest of learning to read any poem as its poet's deliberate misinterpretation ... of a precursor poem' $(30 ; 43)$, comparing this productive interpretive deviation to the atomist clinamen; 'the originary deviation [of an atom in the laminar flow] from which everything follows'. ${ }^{5}$ So, I could justify what follows with a roll-call of Shakespeare's (near-) contemporaries proven to be readers of the atomist and Epicurean philosopher, Lucretius (c. 9955 BC) - Ascham, Bacon, Browne, Chapman, Davies, Donne, Fraunce, Hobbes, Jonson, Milton, Raleigh, Spenser and so on - or an account of indirect influences - via Ovid, Virgil, Sylvester's Du Bartas, Florio's Montaigne, Fracastoro, and, crucially, Epicurus - but instead I shall seek to chart how Shakespeare's dramatic enquiry into chance and the nature of the aleatory subject (a subject to chance or an autonomous subject?) departs from or inclines towards that of his poetphilosopher precursor; 'Know each poem', Bloom concludes, 'by its clinamen' (43). ${ }^{6}$ If for Bloom, a poet's identity is made manifest in their deviation from, or erroneous reading of their literary lineage, for both Lucretius and Shakespeare the identity of atom or character respectively is made manifest in their deviation or errancy from the laminar or narrative line: this is reading for the clinamen.

As Lucretius initiates a discussion of free will, fate, and the accidental with his depiction of struck and rebounded atoms, the Renaissance playwright explores the same inextricable themes in his depiction of the redounded messengers and accident-prone siblings of The Comedy of Errors. Allowing Lucretian atomism to influence a reading of the Shakespearean text demonstrates how both dramatist and philosopher-poet understand the imaginative co-incidence of some seeming dichotomies: chance versus narrative/etiological development; self-determined versus predetermined trajectories; and the destructive or formative potential of accident. What happens, I ask, when something akin to the Lucretian swerve disrupts the narrative trajectories of these Shakespearean characters? Could this seeming disruption actually provide opportunity for the identification of character and for the assertion of private volition?

Pre-post-erously swerving from Bloom's swerve, I offer a hopefully 'creative' (mis-)reading of Lucretius' certainly 'interesting' (mis-)reading of Shakespeare's Error, 'opt[ing] for the clinamen as freedom' (44): or, to appropriate from the sermon of John Harris with which we began, an Unaccountably Invented Senseless Hypothesis about the Oblique Motion of Atoms, which Shakespeare certainly never called the Exiguum Clinamen Principiorum.

\section{A COMEDY OF ERRANDS}

Shakespearean 'comedy [is] sport' (LLL. V. ii. 858): 'bandy[ing] word for word' (Shr., V. ii. 173), his lovers volley badinage like 'tennis balls' ( $A d o$, III. ii. 35) that are 'bandied' back and forth in 'a set of wit well played' (LLL. V. ii. 29). If Juliet's Nurse, an embodied tennis-ball, travels on a frustratingly slow trajectory - 'She [sh]ould be as swift in motion as a ball; / My words would bandy her to my sweet love, /And his to me' (Rom. II. v. 12-15) - then the two Dromios of The

\footnotetext{
${ }^{5}$ Jonathan Goldberg, The Seeds of Things: Theorizing Sexuality and Materiality in Renaissance Representations (New York: Fordham University Press, 2009), 59.

${ }^{6}$ Later influence can be claimed: it begins to seem admissible that Lucretius, at first or second or tenth hand, may have been among the influences which affected Shakespeare during his mainly tragic period' (Martin, 178). Hadzsits concludes that, by the time Burton writes his Anatomy of Melancholy (pub. 1621), 'Lucretius' text was a familiar one to all educated readers' (306). See Stuart Gillespie, 'Lucretius in the English Renaissance', The Cambridge Companion to Lucretius, ed. Gillespie and Philip Hardie (CUP, 2007); L. C. Martin, 'Shakespeare, Lucretius, and the Commonplaces', Review of English Studies, 21 (1945), 174-82; George Depue Hadzsits, Lucretius and His Influence (London: G. G. Harrap, 1935); Jacques Lezra, Unspeakable Subjects: The Genealogy of the Event in Early Modern Europe (Stanford, CA: Stanford UP, 1997).
} 
Comedy of Errors are a pair of miskicked footballs, poorly passed and prone to errancy: 'like a football you do spurn me hither. / If I last in this service you must case me in leather' (II. i. 82-3). While the Nurse shuttles between houses, and while Viola-as-Cesario travels a path of 'give ... [and] take' (TN. III. iv. 204) between courts, the twin Dromios are struck to-and-fro with real violence; like the tennis ball-carrying French ambassador of Henry $V$ whose 'balls [turn] to gunstones' (I. ii. 282) or Cleopatra's messenger whose 'report' (Ant. II. v. 57) is answered by her violent retort, the Dromios are returned with interest:

ANTIPHOLUS S. $\quad$... There, take you that, sir knave.

[strikes Dromio.]

I. ii. 92

Shakespeare's Comedy resounds with these beatings - 'I ... have nothing at his hands for my service but blows' - as the twin messengers are impelled from door to door - 'I am ... driven out of doors with [beating] when I go from home, welcom'd home with it when I return' (IV. iv. 29-37) - struck and restruck by their masters - 'I shall break that merry sconce of yours' (I. ii. 79) - delivered onto their erring errands (to fetch rope, for domestic beatings elsewhere) with remorseless regularity: 'Go back again, and be new beaten home? / For God's sake send some other messenger' (II. i. 76-7).

Following the trajectories of these messengers as they move across the play's interim spaces, we see them travel with not just the impetus of balls struck, hazardously impelled, but with the kinetic impetus of corpora materia in collision, coincidentally coinciding. ${ }^{7}$ As the Shakespearean messenger is struck and rebounds, so too do the Epicurean atoms as ' $\mathrm{t}] \mathrm{hrough}$ the vast space their wandrings [they] renew': 'smitte'n with undiscerned force,' the atoms 'Are oft drive'n back, and often change their course, / Here mount, there sinke, on every side reverst, / All by th'impulsive matter thus disperst' (II. 126-9). ${ }^{8}$ The clash that sends a Dromio on his wandering course is akin to 'the perplext agitations' (II. 124) of principles or particles as described by Lucretius. $^{9}$

Following 'Armies of attoms ... / Meeting in perpetuall skirmishes,' Lucretius' aetiological text, De rerum natura, depicts an interim busy with particular movement and interaction - 'Here joyne, there part, their motions never cease' (II. 15-17) - and, in what follows, I correlate the Lucretian atom with the Shakespearean go-between, and the movement of particles in space with the entries and exits of the Shakespearean actor. So, as Viola/Cesario rebounds from Orsino to Olivia, repeating the words of her beloved, she traces the course of that 'babbling gossip of the

\footnotetext{
${ }^{7}$ The hazard: as part of the court in real tennis ('We will in France ... play a set, / Shall strike his father's crown into the hazard' [HV. I. ii. 213-14]); as the risk of aleatory chance ('I will stand the hazard of the die' [RIII. V. iv. 10]).

${ }^{8}$ Lucy Hutchinson, Translations of Lucretius: De rerum natura, ed. Hugh de Quehen (London, 1996), II. 82.

${ }^{9}$ I offer atomic tennis balls as a complementary alternative to Stephen Greenblatt's bowling balls: 'So come to it, lady, you have been mistook; / But Nature to her bias drew in that' (TN. V. i. 259-60). The swerve of the clinamen as I shall describe it (as formative of both plot convention and identity; and as it tests the complex relationships between determinism, the accidental, and the freely willed), compares to the 'strategic, happy swerving' that Greenblatt sees as 'one of the central structural principles of Twelfth Night, a principle that links individual characters endowed with their own private motivations to the larger social order' (68): 'you reach a desired ... destination not by pursuing a straight line but by following a curved path' (71). Bloom's injunction to read for the clinamen of strong-misreading-as-influence, with which I began, is given its Historicist articulation in Greenblatt's 'it is essential to break away from ... textual isolation ... and move outside the charmed circle of a particular story and its variants. How can we do this? How but by swerving?' (72-3). Shakespearean Negotiations: The Circulation of Social Energy in Renaissance England (Oxford: Clarendon Press, 1988).
} 
air' (TN. I. v. 228), Echo - bouncing 'as a Ball, to and fro' as Bacon describes the 'Reflexion Iterant, which we call Eccho' - ricocheting like Lucretian semina in what he calls the 'ecchoing ayre' (II. 142).$^{10}$ Although Plutarch's description of the atomists' 'little bodies indivisible' explains that they are 'by reason onely perceptible', the intricate movement of the Antipholus and Dromio twins exceeds all perception: ${ }^{11}$

\section{ADRIANA Witness you}

That he is borne about invisible.

Even now we housed him in the abbey here,

And now he's there, past thought of human reason. $\quad$ V. i. 186-9

The passage of characters through the marketplace of Ephesus (an in-between space of interaction) is one of restless activity: even the name, Dromio, denotes "one who runs/races". ${ }^{2}$ 'Desperately [they are] hurried through the street... rushing' (V. i. 140-3) from encounter to encounter, 'here and there' (147). No 'stay' (20), no 'arrest' (IV. ii. 43), can hinder their movement 'as they clash, some rise, others descend / ... [but n] o stoppage in their swift declension find' (De rerum, II. 82-9), making their 'strong escape' from being 'bound' (V. i. 145).

The Lucretian universe incorporates both an energetic tumble - a lack of rest, a mutability troubled by 'secret tumults in the matter' (II. 125) - and an intrinsic abiding order, a stricter union, an interweave that allows dilation within its flexible compass:

The principles rest not in any place:

But dayly chang'd in motion still abide;

Some in loose order joynd, extending wide;

Some that touch neere, with stricter unions closd,

Into a narrower compasse are disposd;

And interwoven soe, they cannot spread.

... But they

Which from each others touch doe start away,

And in a wider scope themselves dilate.

De rerum, II. 97-106

'The Nature of Things is coordination and disjunction', explains Gilles Deleuze, 'Neither identity nor contradiction, it is a matter of resemblances and differences, compositions and

decompositions. ${ }^{13}$ Accordingly, Michel Serres identifies two responses to Lucretius' description of the emergence of matter and form from chaos. Firstly, we may see only a world of fluxion:

The ... unrest or perturbation is a limitless empty space traversed by movements, collisions, intervals, paths and weights, distributed at random, without conjunction, scattered, opposed, disjunct. The Epicurean rediscovers Empedocles: struggle, war, hatred. Collisions and encounters without union. ...

\footnotetext{
${ }^{10}$ Francis Bacon, Sylua syluarum (London, 1628), 67; 64.

${ }_{11}$ Plutarch, The Philosophie, commonly called, The Morals, trans. Philemon Holland (London: by Arnold Hatfield, 1603), 807.

${ }^{12}$ See T. G. Bishop, Shakespeare and the Theatre of Wonder (CUP, 1996), 77. See also p. 78: 'The body of a Dromio is an object at the mercy of physical laws'.

${ }^{13}$ Gilles Deleuze, The Logic of Sense, trans. Mark Lester (London: Continuum, 2004), 305. See Goldburg,

The Seeds of Things, 157.
} 
All is 'crumbled out ... to his atomies', as Donne complains; 'Tis all in pieces, all coherence gone; / All just supply, and all relation'. ${ }^{14}$ Alternatively, we see how order emerges from, or is latent within this flux:

... here are translations, rotations, chance vibrations, here are the places of rest for the points of collision, momentary equilibria, deviation. Is it possible that at indefinite times, in unforeseeable places, here or there, yesterday or tomorrow, all these phenomena may suddenly add up, all the contradictions resolve? There is no reason why all these characteristics should not, somewhere, be copresent. ${ }^{15}$

'Order or disorder, it is difficult to decide,' Serres concludes, 'disjunction is arrangement' (27). Like a spinning top, there is whirl and jump, but all in the aid of stability - 'Is it stable? Yes. Is it unstable? Yes, again' (29) - and so there is turbo (an ordered spiralling) and there is turba (a disordered turbulence) (30), fluctuation and fluxion.

Serres's description can be redeployed, his collapsing binaries employed to account for some of the differences between Shakespeare's comic and tragic vision. Put simply, the movements of bodies on Shakespeare's tragic stage - for instance, Lear's world of intercepted messengers, fraudulent posts, crossed paths, dispersed family units, violent opposition, and natural perturbation - are answered in the comic trajectories of The Comedy of Errors. ${ }^{16}$ What was once 'unrest or perturbation' reveals a latent teleological structure; the 'rotations' come to a point, and the 'chance vibrations' reveal their stochastic patterning as 'all that are assembled in this place [are] sympathized [by] one day's error' (V. i. 397-8). We move from initial structure, through turbulence, to a new sympathetic order. If the moment of comedic expository unveiling could offer 'full satisfaction' (400) in 'this present hour' (402), then perhaps, to answer Serres, it would be 'possible that $\ldots$ all these phenomena may suddenly add up [and] all the contradictions resolve'.

This characteristically Shakespearean investment in the aptness, hap-ness, or perfection of comedic conclusion - usually achieved by revealing the contingent (OED 1a. touching each other: in contact) within contingency (OED 4. happening by chance) - drives narrative towards the coherence and immediacy of a 'present hour', answering Lear's 'present business [of] general woe' (Lr. V. iii. 318-19). Denied narrative resolution, Kent has 'a journey, sir, shortly to go' and must bear 'the weight of this sad time' $(322 ; 324)$; whereas, after her 'Thirty-years [of] travail', Aemilia's 'heavy burthen' (Err. 401-3) is lifted. The 'sad steps' of Lear reveal only 'difference and decay' (Lr. 290; 289) as the paths of tragedy follow their scattered, opposed, disjunct routes to their horrific 'promis'd end' (264); whereas the seemingly deviant or divergent routes of Shakespeare's Comedy 'accidentally are met together' (Err. 362) as coincidence is revealed as coincidence, what was felt to be contingent discloses causal contiguities: whereas, in Lear, the 'chance which [would] redeem all sorrows' (Lr. 266) is denied, 'there is no reason' why the

\footnotetext{
${ }^{14}$ John Donne, 'An Anatomy of the World: First Anniversary', The Complete English Poems, ed. A. J. Smith (Harmondsworth: Penguin Books, 1996), 212-14.

${ }^{15}$ Michel Serres, The Birth of Physics, trans. Jack Hawkes, ed. and intro. David Webb (Manchester: Clinamen Press, 2000), 30.

${ }^{16}$ Further conflations can be made between the passage of the contaminative atom and the transmission of infectious letters (as Donne describes letters that 'come as Atomes'): each letter that is carried across the Shakespearean stage can be metonymically understood as atomic. John Donne, Letters to Severall Persons of Honour (London, by J. Flesher, 1651), 74. For discussion of epistolary exchange in Lear, see Alan Stewart, Shakespeare's Letters (OUP, 2008), and Jonathan Goldberg (esp. Shakespeare's Hand [Minneapolis: University of Minnesota Press, 2003], and Writing Matter: From the Hands of the English Renaissance [Stanford UP, 1990]).
} 
Comedy should not fortuitously add up. Turbo or turba: the passage of semina and drama alike follow a centrifugal comedic course or a centripetal tragic trajectory.

So, we can read Lucretius two ways: if, as De rerum natura's central tenet insists, 'Tis proovd that nothing out of nothing springs' (I. 210), we can rehearse this with tragic fatalism - 'Nothing will come of nothing' (Lr. I. i. 90) - or with fertile comic wit: 'this [is] something you gave me for nothing' (Err. II. ii. 51-2). Serres's binary readings of Lucretian atomic movement - turba-fluxion versus turbo-fluctuation - map the divergent routes of tragic and comic declination: on one hand narrative obeys the tragic weight, pulled to a 'Fall, and cease!' collapsing in a trajectory of 'great decay' towards the 'cheerless, dark, and deadly' (Lr. 265; 298; 292) in an atomic 'dead march'; on the other, the comic narrative makes concord of this discord as 'every why [coincides with its] wherefore' (Err. II. ii. 43), and all falls out pat.

In its primal state of chaos, the Lucretian universe is far from chaotic: 'Bodies [fall] in a streight line, with their owne weight / Borne downe, in the vast space' (II. 21112), in a laminar flow of atoms that 'all in a descending current swiftly fall' (II. 448). This is the straight decline - the thalweg - that exists before the formation of form, moving in a curiously inert descent, an orderly chaotic rain: no difference, no alterity; hence no form, no identity.
In its opening movements, the Comedy's universe is far from chaotic. Bodies embark on 'prosperous voyages' (I. i. 40) that 'safe, arrive' (48), congruities shape the narrative - 'That very hour, and in the self-same inn...' (53) - and no alterity disturbs the geminative structural flow: the 'twins both alike' (55) are 'one so like the other / As could not be distinguished but by names' (51-2). We set sail on calm currents, 'floating straight, obedient to the stream' (86).

Then, into the calm currents, cuts the clinamen - the Lucretian swerve, the Shakespearean rock the 'suddaine blow [that will] change the motion' (II. 236-7): 'Now here is the deviation of the declination', Serres explains, 'introduc[ing] acceleration into the flow' and 'thus a force [a]nd dynamics appear' (46); 'things are the products of the chance meeting of atoms,' Goldberg glosses, 'which otherwise would continue falling, untouching and unproductive' (2). Lucretius explains:

Bodies in a streight line, with their owne weight

Borne downe, in the vast space alter their state, When both in an uncerteine time, and place,

Suddaine concussions force them to give space;

For if they were not thus us'd to decline,

Like drops of raine, they all in a streight line

Would fall into the vast profunditie,

Soe noe concursions, nor no touch could be

Allowd the principles, and by this way

Nature could nothing frame; but if some say

The heavie bodies in their swift fall hitt

Upon the lighter, and doe soe beget

That touch, which generative motion breeds,

They tread the path which to wild error leads. 
The rainfall of atoms is disturbed: perhaps by a sudden concussion; perhaps ('some say') caused by heavier primordia falling too fast; perhaps by chance (and the clinamen is frequently understood as synonymic to chance); ${ }^{17}$ perhaps by wilful intervention or impulse (and we shall see how Lucretius compares this atomic swerve from the determined path with the decisive inclinations of the freely willed). ${ }^{18}$ For all these reasons, or for no clear reason, creation is initiated. As one atom from one strand of the laminar flow executes its swerve a 'declination, angled obliquely, traverses the field of atoms' (Serres, 31), inscribing the path of a clinamen: 'The lightning declines, the clinamen blazes, amidst the sheet of water' (31). Cutting across the thalweg, the clinamen causes obstruction, difference, errancy, a bottle-neck behind which matter accumulates, allowing complex structure to occur as it stacks up behind a swerve that frames, that generates, that breeds form. 'Order', Serres summarises, 'comes stochastically from disorder' (89). This is the new, formative, and creative 'path to which wild error leads'.

And this is the new path - from homogeneity into difference, from inert structure to energetic narrative confusion - down which The Comedy of Errors is led: the latent sense of 'errancy' or 'wandering' in 'Error' is disclosed, but not simply to suggest self-loss but also to provide an opportunity for self-discovery. The clinamen swerve operates with generative errancy. 'The nimble stroke of quick cross lightening' (Lr. IV. vii. 34) cuts across this text as the shipwreck that divides the family cuts through the lamina flow: 'thunder and lightening model the clinamen' (Serres, 86):

[They are] encountered by a mighty rock, Which being violently borne upon, Our helpful ship was splitted in the midst; So that in this unjust divorce of us Fortune had left to both of us alike What to delight in, what to sorrow for.

Shakespeare disturbs the geminative 'both ... alike' stasis of twins, siblings, nuclear families, with a quick flash of lightning - sent by Fortune, or by Prospero, dividing Viola from Sebastian, the Turk from Cyprus - or a chance ship-wrecking encounter. Dramatic event can now start to stack-up behind the 'oblique course' (De rerum, II. 246) of Shakespeare's narrative clinamen. ${ }^{19}$

\section{A COMEDY OF ERRANCY}

At first it seems that the chancy accidental swerve, with its hap-hazard indiscriminancy, has undermined the intrinsic uniqueness of these identically named characters: 'I will go lose myself / And wander up and down to view the city' (I. ii. 30-1). The errant Antipholus loses distinction in the marketplace (a locale that admits an early-modern anxiety - both fiscal and ontological -

\footnotetext{
${ }^{17}$ Although Deleuze denies this, arguing that 'the clinamen ... is the original determination of the direction of the movement of the atom' (306): a kind of latent inclination.

${ }^{18}$ Karl Marx, in his doctoral dissertation of 1841, describes the curve of the clinamen as an emblematic assertion of independence in the face of deterministic tyranny. See William Kerrigan, 'Atoms Again: The Deaths of Individualism', Taking Chances: Derrida, Psychoanalysis, and Literature, ed. Joseph H. Smith and Kerrigan (Baltimore: John Hopkins UP, 1984), pp. 86-106, 99.

${ }_{19}$ The forked lightening of the clinamen: the split mast of the Comedy. Bishop points out that this split mast is 'original with Shakespeare's version [and] bound up with the poetics of narrative in the play' (79). Bishop quotes Lars Engle (personal correspondence) on how the position of characters clinging to the mast dictates the sequence of speakers in the play: order depends on, clings to, this split.
} 
concerning the loss of intrinsic worth, a crisis of exchangeability, the circulation and hence reevaluation of values or identities), where the evaluation of others seems to supersede any sense of self or self-worth. ${ }^{20}$ The wanderers, from Syracuse in particular, experience the turbulence in fluctuation - 'Am I Dromio? Am I your man? Am I myself?' (III. ii. 72) - identifying only error (mistake) in error (OED 1.I. The action of roaming or wandering), only the threat of effacement in potentially formative alterity; 'I am in adversity' (IV. iv. 19) is the first fearful response that must ultimately cede to the mature realisation that 'I am [because of adversity'.

'Wander[ing] in illusions' (IV. iii. 36), the first recourse is not to submit to the clinamen but to pray that 'Some blessèd power deliver us' (37). Any invocation of the divine - 'Are you a god?' becomes increasingly farcical - 'Would you create me new?' - increasingly naïve in a godless Lucretian universe and in this Shakespearean world of decidedly human incomprehension and confusion. 'Transform me, then,' Antipholus of Syracuse begs Luciana, 'and to your power I'll yield' (III. ii. 39-40), but perhaps the power here resides in the transformative, metamorphic energies of the mutable world and its Epicurean 'mutations' (De rerum, I. 815). Crucially, although showing how 'everything that exists is the result [not of deterministic or providential intervention but] of aleatory conjunctions' (Goldberg, 1), Lucretius does not leave us wandering in error, free-floating: as atoms collide, structure will form; as characters interact, narrative ensues. The cohesion of atoms/characters brings coherence of form/narrative; what was stochastic feels increasingly fortuitous: the contingent accrues causality.

We may want to distinguish between Aristotle's two models of chance - automaton (the automatic, self-moving, and causeless) and tyche (deliberate, intentional, or intrinsically apt) - that are illustrated by an encounter with a rock, and an encounter in a marketplace ('He met me on the mart...' [III. i. 7]):

Nothing happens by chance, but that everything we ascribe to chance or spontaneity has some definite cause, e.g. coming by chance into the market and finding there a man whom one wanted but did not expect to meet is due to one's wish to go and buy in the market. ... [Wheareas] the spontaneous is ... the case in which the thing itself happens in vain. The stone that struck the man did not fall for the sake of striking him. ${ }^{21}$

If the automative is purely stochastic - truly random and undeserved - tyche is deterministic; in practice, an Aristotelian chance event is rarely truly random. ${ }^{22}$ The distinction helps distinguish between the Comedy's accidental and erroneous moments: subject to the sea's stochastic fluxion, a boat is hit by a rock; circulating around the marketplace, debtors and the indebted coincide, only seemingly at random. The automaton instigates the narrative, but the causality of this narrative quickly dictates a shift into tyche: the causeless event initiates causal chains; the stochastic clinamen determines structural coherence. Shakespeare's drama allows us to make Aristotelian distinctions between random event and destiny, while distinguishing between paradoxical definitions of the

\footnotetext{
${ }^{20}$ See Jonathan Gil Harris, Sick Economies: Drama, Mercantalism, and Disease in Shakespeare's England (Philadelphia: University of Pennsylvania Press, 2004) and Georg Simmel, The Philosophy of Money, trans. Tom Bottomore and David Frisby (London: Routledge and Kegan Paul, 1978).

${ }^{21}$ Aristotle, Physics II, in The Complete Works, ed. Jonathan Barnes, vol. 1 (Princeton UP, 1984), 196a1 1-5; 197b1 25-30.

${ }^{22}$ Aristotle uses the Greek equivalent of 'accident' sumbebekos to distinguish 'the mutable or inessential qualities of a thing from its defining essence or substance. He used the same term to refer to accidental events, so a link between unexpected events and the defining qualities of a person or thing appears at the beginning of the history of accident.' Again, the formation of identity is contiguous with the operations of the accidental. Ross Hamilton, Accident: A Philosophical and Literary History (Chicago: University of Chicago Press, 2007), 1.
} 
Lucretian clinamen: are his characters beset by automated or determined accidents, the swerve of stochastic chance events or by the inclinations of their own wills? In the Ephesian marketplace, we are asked to discriminate between self-volition and determinism, between identities determined by error and errors determined by identities. ${ }^{23}$

Aleatory subjects - dependent upon the hazard of the dice rather than upon self-determination feel subjected to forces beyond their control (a paradoxical distinction: chance is not determined but gives the impression of determinism) $:^{24}$

Proceed we then to treate what motions doe

Dissolve all creatures, and their frames renew;

Whither first bodies, by impulsive force,

Or mooving faculties, maintaine their course.

De rerum, II. 60-3

One Dromio, as indistinguishable from his twin in appearance as he is in name, may attempt to claim individuality (my 'mooving faculties' are my own), but each is repeatedly thwarted by the suspicion that their individualities are inextricably in-dividual, indivisible, each from the other. ${ }^{25}$ The unique autos of each is perpetually undermined by the realisation that they are the 'same', that one can substitute for another, as extrinsic circumstances impinge indiscriminately, refusing to acknowledge their private inclinations (my movement is compelled by an outside impulsive force'). Both atom and servant find 'their mooving power provoke[d], / By the impulsion of ... secret strokes' (II. 132-3), their knock-on activities driving both kinetic interaction and narrative causality while undermining all confidence in their self-volition; the movement of each single elementum could be understood as its impelled response to a causal chain -

These moovd by them, moove the next rank, from whence Motion proceeds, untill it meete our sence.

De rerum, II. 132-5

- just as each single Dromio is indiscriminately bound into the undecipherable causal developments of what feels like a terrifyingly tyrannical narrative sequence:

DROMIO OF EPHESUS She is so hot because the meat is cold.

The meat is cold because you come not home.

You come not home because you have no stomach.

$\begin{array}{ll}\text { You have no stomach, having broke your fast. } & \text { I. ii. 47-50 }\end{array}$

Throughout the play, characters neurotically return to these declinations that insist on causal continuities and descending, dependent logic. Against the suspicion that the unfolding events are indifferent to their individual wills - a Dromio is a Dromio is an Antipholus is an Antipholus these sequential rehearsals attempt to impose a self-willed narrative on what increasingly appears to be random or inexplicable ("this chaos is explicable", they suggest, "everything happened because you chose to eat an early dinner"). As Michael Witmore describes:

\footnotetext{
${ }^{23}$ I would amend Dean Kennedy's assertion that 'we are asked to accept that everything we consider makes us what we are - our consciousness, our senses - is purely an epiphenomenon, the chance combination of particular atoms moving in particular ways', to 'we are asked if we accept...' (Rethinking Reality: Lucretius and the Textualisation of Nature [Ann Arbor: University of Michigan Press, 2002], 2).

${ }^{24}$ As Kott reads Lear, you are beset only by accidents in a world where the Gods do not listen, and you who grotesquely hope to be a tennis-ball of the gods, or a fly to wanton boys - may cry out to Fate or Fortune, but, really, randomness reigns. Jan Kott, Shakespeare Our Contemporary (London: Methuen, 1964). ${ }^{25}$ See Jeffrey Masten, Textual Intercourse: Collaboration, Authorship, and Sexualities in Renaissance Drama (CUP, 1997).
} 
Knowing that he lacks the authority to impose an organization on events, Dromio perceives that any attempt to explain what has happened - which will involve boiling the sequence down into some causal nexus - is simply going to make matters worse.

The play, he concludes, becomes 'one long [and frustrated] attempt to give a narrative account of accidents. $^{26}$

But the Lucretian clinamen - and, I will now argue, this Shakespearean Comedy - should not be understood as posing a threat to individual identity; as Serres explains:

What astonishing nonsense to compare the atom with the individual: for the atom without clinamen is death pure and simple, the return to chaos, or the chaos which precedes birth. The natural individual, living and feeling, ... is atom plus clinamen, ... atom plus liberty, will, pleasure.

Serres, 186

Inclined towards errancy, we are introduced to difference - 'the clinamen is ... a differential' (Serres, 4) - as Antipholus of Syracuse is differentiated from Antipholus of Ephesus, or, as the earliest stage directions nominate them, 'Antipholus Erotes' (the wandering) and 'Antipholus Sereptus' (sureptus: snatched away). Although 'severed from ... bliss' (118), they are born into dividuality through experiencing division. This is what has 'befall'n' (123) them, interrupting their previously indistinguishable falling currents, disrupting their flow with the introduction of 'reft' (128) into their narrative drift. The clinamen - the 'extremity of dire mishap' (141) - produces the 'hazard' (131) and dividual uniqueness of aleatory identity. Without this intervention, this swerve, identity is left undelineated, because 'if motions are together tied' and a 'certeine order their successions guide' then 'noe declension of first bodies can / Produce new principles' that would 'breake the chaine / Of destinie' (De rerum, II. 249-52). The determinism of destiny - the 'linking causes [that] bring... / Fatall necessitie on humane things' - would deny our 'freedome then to doe / Whatever [our] owne pleasure prompts [us] to' (II. 252-5): only the clinamen, here synonymous with the 'free and fate-resisting-will', allows us to 'change our motions as we change our mind' and take responsibility as 'sole author of each humane deed' (II. 56-60). Without the clinamen, the inclination of the subject, we are left 'floating in the vast immensitie' of the thalweg, incapable of formative interaction, of realising an individuality predicated upon indivisibility with an encountered other.

Perhaps it seems as if the Ephesian marketplace is governed by random event, that private identity is of secondary importance in this world of exchangeable names, endless re-evaluations, and circulating tokens. Perhaps it seems that autonomous individuals are, in this theatrical mart, no more than aleatoric automatons. But, no matter how exchangeable one Antipholus or Dromio is for the other - indeed, no matter how close they come conceding their own indistinctiveness - the play does no more than flex and test the extricability of social role-fromidentity, identity-from-name, name-from-reputation, and reputation-from-social role; ultimately it is Antipholus of Ephesus who is married to Adriana, and Dromio of Syracuse need not take his place and slip between the sheets with his brother's 'fat friend' (V. i. 414): it does make a difference that 'She now shall be my sister, not my wife' (416). The play joins Serres in celebrating 'the small difference ... of identity ... of indiscernables' (32); 'This week he hath been heavy, sour, sad, / And much, much different from the man he was' (V. i. 45-6). This

${ }^{26}$ Michael Witmore, Culture of Accidents: Unexpected Knowledges in Early Modern England (Stanford: Stanford University Press, 2001), 72; 66. 
Comedy ultimately affirms identity - 'I am myself deviation', Serres announces - rediscovering an order not lost but misplaced - 'Who am I? ... Yes, a singularity, a singular' - identifying and eradicating error rather than submitting to the hazardous indiscriminancy of the accidental, and thereby obeying the formative errancy of the clinamen that allows identical atomi/Antipholi to achieve difference, to achieve dividuality: 'This slanting lightning bolt governs me' (Serres, 37-8). Shakespeare plays out the construction, not destruction, of the individual.

At several moments in De rerum natura, Lucretius compares atoms (elementum) with letters, and the clinamen-induced co-incidences with the construction of word: 'of things, it ... may be sayd / [that they are] as words ... out of many letters made' (I. 200).

Everything drifts ... from the original atoms, the backdrop ... and so it is with words, these shifting aggregations of atom-letters. Here is the origin of meaning, the transverse lightning-flash on the backdrop that is the background noise. Sense is nothing but its slope, it is the sense of the slope. It is another drift.

Serres, 34

Just as 'the same principles doe constitute / Heave'n, earth, sea, sun, floods, creatures, plants and fruite / ... So in our verse are common letters found / In severall transpositions sett, from whence / Words are produced, of severall sounds and sence' (I. 830-5). As the clinamen cuts across the laminar and alphabetical flow, the letters A, I, L, O, and V stack up, and in 'divers ways their divers beings compound' (I. 832) into V I O L A, or O L I V I A, or M A L V O L I O. And although we may see this as testament to the exchangeability of identity in Shakespeare's comic universe - after all, a HER M I A f fairly easily exchanged for a HELEN A - the play ultimately affirms the aptness and distinction of the name: 'each circumstance / Of place, time, fortune, do cohere and jump / That I am Viola' (TN. V. i. 251-3). ${ }^{27}$ The errant ways of fortune and circumstance, or chance and coincidence, swerving forwards from the moment that the 'ship ... split' (I. ii. 9), have brought Viola back to her distinct name: 'a signal and a meaning [have] emerge[d] from the noise', Serres would argue; 'How? By declination, by drift' (135). Finding that 'M. O. A. I. doth sway my life' (II. v. 107), Malvolio is thrust into 'the trick of singularity' (151-2), even if his declination has been a decline. By jumbling up these constituent letters, 'turbulence

\footnotetext{
${ }^{27}$ Derrida's work on the 'postal principle' provides a productive correlative to my discussion, charting an errancy that disturbs the transportation of letters and words - the destinerrance of the post or 'the aleatory destinerring of the envoi' - that correlates with the errant progress of my atomic characters (Jacques Derrida, 'No Apocalypse Not Now', Psyche: Inventions of the Other, ed. Peggy Kamuf and Elizabeth Rottenburg [Stanford UP, 2007], pp. 387-407, 405). His discussion of the Lucretian clinamen ('My Chances/Mes chances: A Rendezvous with Some Epicurean Stereophonies', in Kamuf, pp. 344-76) is perhaps more apt for a discussion of Lear's tragedy than Shakespeare's Comedy, as his anti-Lacanian insistence on the letter's potential not to arrive dictates an emphasis on the aleatory nature of names (that fail to arrive; that designate or iterate almost accidentally; 'the divisibility of the mark' [360]). As Leland Monk describes, 'Derrida uses the Epicurean-Lucretian concept of the clinamen, the always possible and hence structurally defining element of chance in an atom's makeup, to describe chance's influence on the movement and meaning of any linguistic unit', concluding that 'Derrida argues that the atomistic nature of the proper name is structured by a clinamen that can interrupt or divert the dispatch's circular route to its eventual and destined destination' (Standard Deviations: Chance and the Modern British Novel (Stanford: Stanford University Press, 1993), 99-100). This accounts well for the interrupted posts of both comedy and tragedy, if we allow the eventual arrival of the letter/word in comedy to correlate with the generation of stable form that ultimately results from the clinamen's disturbing swerve. Derrida himself appreciates the best fit of 'Mes chances' with Lear: 'my regret [is] not having attempted with you, as I initially projected, an analysis of King Lear ... . I would have followed the play of Nature and Fortune ... of the very numerous "letters" ... of "epicurism" of "posts" (374).
} 
[has] disturb[ed] the chain' and in so doing has 'trouble[d] the flow of the identical' (Serres, 110) to create formative difference.

The clinamen's introduction of formative difference, for Lucretian-influenced thinkers such as Edward, Lord Herbert of Cherbury, facilitates the development of an ontology predicated upon deviation from the standard, where 'every difference contains some principle of individuality. ${ }^{28}$ An Antipholus is Antipholus X to the extent that he is not Antipholus Y: 'the difference [or in Lucretian terms, the inclination] touches the individual essence of the thing' (85). The difference between VI OLA and OLIVIA, Or OF E P HESUS and OF SYR A C USE, is the difference that is individuality: 'differences, therefore, possess the value of objects, whether they are detected in things, [or] in words, in signs' (85).

\section{A COMEDY WITHOUT ERRORS}

To keep track of yourself, you have - like Montaigne as he submits to the flux - to roll with the clinamen; you have to treat the deviation as standard:

ANTIPHOLUS S. What error drives our eyes and ears amiss? Until I know this sure uncertainty, I'll entertain the offered fallacy.

To enter the liminal space - 'Am I in earth, in heaven, or hell? / Sleeping or waking?' (203-4) and to 'wander in an unknown field' (III. ii. 38), requires a certain flexibility, a willingness to entertain the fallacy, to allow wandering errancy and adopt a receptivity to the adventure of declension: 'I'll say as they say, and persever so, / And in this mist at all adventures go' (206-7). Or, as Hamlet says upon his acceptance of narrative drift, 'let be' (Ham. V. ii. 224).

In Hamlet, Shakespeare moves between the alternative senses of 'declination', where to 'decline' is both to fall straight down (as if in the rain of the thalweg), or to traverse an incline (as if on the cut of the clinamen). It seems, as Pyrrhus' sword is 'declining on the milky head / Of reverent Priam' (II. ii. 478-9), that this decline is cognate to the declensions of a simple 'fall': 'falls ... fell ... falls ... fall ... now falls on Priam' (470-92). But elsewhere the decline reveals will and inclination, demanding individual response (i.e. revenge) to the murder of Old Hamlet that has knocked the play 'out of joint' (I. v. 188). Consequently, Hamlet's sick inclinations, according to the diagnosis of Polonius (who constantly attempts to '[o]bserve [the] inclination' [II. i. 68] of others), are the result of a knock-back, a repulsion from the seemingly 'accident[al]' (III. iii. 30) 'encounter' (II. ii. 164) with the 'loose' (i.e. errant, 165) Ophelia, from which Hamlet is 'repell'd', and away from which he '[f]ell' along the kinetic causal chain 'into a sadness, then into a fast, / Thence to [a] lightness, and by this declension, / Into the madness wherein now he raves' (14650). From such 'slender accident[s]' (III. ii. 199) come declines and inclines. So, Hamlet knows that it is his mother's errant inclination that has caused her bed-swerve, her dextrous 'post' (I. ii. 156), and that her trajectory is, as his father tells him, a 'decline' (I. v. 50), an 'err[ancy]' in her self-determined 'motion' (III. iv. 72; 73), revealing dreadful 'difference' (76) in her 'falling-off' (I. v. 47) from brother to brother: 'My father's brother, but no more like my father / Than I to Hercules' (I. ii. 152-3). For good or ill, the declination reveals inclination; the falling from lineal line (from father to son, from H A M LE T to H A M LE T) has revealed difference, has delineated

${ }^{28}$ Edward, Lord Herbert of Cherbury, De Veritate [1624], trans. Meyrick H. Carré (Bristol: J. W. Arrowsmith, 1937), 86. 
identity, just as the declension of the relative pronoun in William's Latin lesson in The Merry Wives of Windsor reveals distinctions between the 'who', the 'which', and 'he':

EVANS Show me now, William, some declensions of your pronouns.

WILLIAM Forsooth, I have forgot.

EVANS It is qui, [quae], quod: if you forget your quis, your [quae]'s, your quod's, you must be preeches.

$M W W$ IV. i. 74-9

We are beaten from the laminar flow, whipped (preeched) into difference, into differentiation, into distinction: first, 'this is I, / Hamlet the Dane' (V. i. 257-8); then Serres once more: 'I am myself deviation'.

But although 'I am myself deviation', we need not be one of those 'many loose bodies ... / Which [are] nere receiv'd into societie,' and 'Alone wander through this vast extent' (De rerum, II. 108-10). The Lucretian clinamen, although constitutive of or analogous to the individual will, also initiates constitutive coincidence, kind contact, cross-contamination, and conversational compacts: 'Did you converse, sir, with this gentlewoman? / What is the course and drift of your compact?' (Err. II. ii. 151-2). The individual atom, like the early-modern subject, achieves individuation through indivisibility with an other. And it is in our interactions that we describe our inclination:

ANTIPHOLUS S. But if that I am I, then well I know

Your weeping sister is no wife of mine,

Nor to her bed no homage do I owe.

Far more, far more to you do I decline.

Err. II. i. $41-4$

A subject to accident, Antipholus of Syracuse finds his identity in response to the swerve, refusing to be simply akin to his identical brother, instead finding kindness (' $\mathrm{I}$ am thee' [66]) in the heterosexual differential reflections of Luciana to whom he 'decline[s]' by declining Adriana: 'thyself, mine own self's better part' (III. ii. 61-4). Not only impelled towards the reunion of divided kin but also seeking to make distinction between them, the Comedy therefore offers sustained examination about the nature of indivisibility, forcing a family unit predicated upon identical identities into its dividual halves, before allowing them to fall into new structures of kin and kind. The Dromio twins, merely bondsmen, delight in their geminative reunion:

We came into this world like brother and brother,

And now let's go hand in hand, not one before another.

V. i. $423-4$

But we catch the implicit suggestion that this regression back to the homogeneity of the laminar flow is a retreat into the narcissine and slightly laughable structures of identities predicated upon identical identification: 'Methinks you are my glass, and not my brother. / I see by you I am a sweet-faced youth' (V. i. 417-18). Formative differentiation, the clinamen's distinctive gift (or gift of distinction), goes begging.

Although initially introducing '[u]nkindness' (II. i. 91), the clinamen's swerve, as it cuts across the identikit atomic descent, is prelude to new kindly coincidence, new relations predicated upon unity-in-difference: 'use her with more kindness' (III. ii. 6). The discussion between Luciana and Adriana (sisters, but, as their unmistakable names suggest, less implicated in models of identical identification) opposes liberty against constraint, debating whether a wife can 'bear some sway' 
or must 'practice to obey' (28-9), their mock misogynist discussion replaying the play's governing discursive dialectic that juxtaposes agency against determinism. The ambition of the Lucretian atom is to yoke, to hook, to get hitched: while the Dromios - thinking it mere 'accident $[.$. that they] are met together' (V. i. 347-51) - begin their hand in hand march back into the undifferentiating thalweg (a "Dromio" is not simply "one who runs" but one who trickles down); the Antipholus twins - redistributing the pronouns as they bring their errancy home ('I was ta'en for him, and he for me' [387]) - are settling down behind the clinamen in new, married combinations. ${ }^{29}$ If the Dromio twins demonstrate that, to appropriate Goldberg's description of atomism, 'at the most elementary level everyone and everything is made up of the same stuff', the Antipholus twins acknowledge that 'this sameness does not preclude difference' (13).

As we have seen, and as Leland Monk explains, 'atomic theory ... grants a positive, formative, creative status to chance and insists that the resultant configuration of atoms is organised according to regular and recognisable patterns'; consequently, Monk invites us to conflate atomic and narrative dynamics, continuing:

When atoms aggregate as the result of the clinamen, they form increasingly complex and stable entities. This is how I see the permutations and fluctuations of chance in narrative as giving rise to increasingly complex, innovative, and eventually stable (that is, conventional) narrative forms.

\section{Leland Monk, 5}

'I, sir, am Dromio' (V. i. 336): the involuted permutations of interaction in the Comedy's marketplace cede to the stabilising strategies of comedic closure - 'thou art Aemilia' (347) - as the regular and recognisable - 'I came from Syracuse' (364) - emerges from the creative and complex - 'I came from Corinth' (365) - demonstrating how 'aleatory elements ... are expunged in the course of the narrative' (8). To appropriate Julia Jordan's formulation of causal twinship, 'no effect ever becomes detached from its cause, and no cause ever fails to bring its twin effect into being'; narrative stacks up. ' 'I am your master, Dromio' (412); the heteronormativity and hierarchical nature of Comedy's ending, where the homosocial becomes the preserve of the comic bondsmen while heterosexual union is the reward for the moneyed and matured, is one aspect of such a conventional standardisation. As Peter Brooks explains, in his equally re-applicable description of the 'textual energetics' of the novel, 'the anticipation of retrospection [i]s our chief tool in making sense of narrative[;]... we read in a spirit of confidence, and also a state of dependence, that what remains to be read will restructure the provisional meanings of the already read. ${ }^{31}$ This retrospective restructuring reveals the fortuitous structures of what once seemed stochastic, rewriting automaton as tyche, the accidental element as plot device, chance as means to this end, until 'no novelist [or dramatist could ever] actually manage... to represent chance in narrative' (Monk, 9), and no character can avoid the impulse to explicate and hence expunge the error's erroneousness: 'I was ta'en for him, and he for me, / And thereupon these errors are arose' (V. i. 388-9). Thus explained, these errors are just meetings in the Aristotelian marketplace, defused by the comforting causality of 'thereupon'. 'Chance marks and defines a fundamental limit to the telling of any story,' Monk concludes: it 'is that which cannot be represented in narrative' (9); chance, as Jordan explains, becomes defused and 'embedded in the

\footnotetext{
${ }^{29}$ I shall appropriate Bishop's observation, used to demonstrate the time-driven impetus of the play, that 'Dromio's tale ... is told insistently in serried lines' (78): for Bishop, the serried lines hurry forward with lineal urgency, whereas for me they fall, declining from and depending upon each other.

${ }^{30}$ Julia Jordan, Chance and the Modern British Novel: From Henry Green to Iris Murdoch (London: Continuum, 2010), 4.

${ }^{31}$ Peter Brooks, Reading for the Plot: Design and Intention in Narrative (Oxford: Clarendon Press, 1984), 23.
} 
predetermined narrative structure of the text' (viii). From fluxion to fluctuation to form: 'Nothing is absurd here, everything is exact, precise, and even necessary' (Serres, 7). ${ }^{32}$

'Matter ... fall[s] / ... into like conjunctions, and frame[s]' new unions, new bodies (De rerum, II. 1089-90); the 'congregat[ions]' (1099) of 'generative bodies ... / All floating in the vast immensitie' (547-9) come to 'composition' (548), 'assembl[ing and] joyn[ing]' (550) as the previously 'dispersed parts combine' (551) and the 'confus'dly scattered' 'unite themselves, in that perplexed flood' (552-3). That which was shattered by shipwreck - 'as in storms, when the strong vessells crack / And fall to pieces in that violent wrack / Plancks, rudders, sayle-yards, decks, masts, floating oares, / And all the tackling cast on severall shores' (554-62) - or that which 'flow[ed] / In loose confusion, where unfixed they / Could neither joyne, nor in conjunction stay' (563-5), now meet, now marry:

Soe of hookt attoms that together stick

Are made all bodies, which seeme firme and thick.

Exeunt, to gossip at the wedding feast.

\section{CONCLUSION: A TRAGEDY OF ERRORS}

In conclusion, some account must be made of the final movements of De rerum natura:

Now I the reason of disease shall render

And tell what causes killing plagues engender

Whence suddaine death of men and beasts proceeds.

De rerum, VI. 1143-5

Having established this generative model of atomic interrelation and the formative potential of interaction, Lucretius finds his abrupt conclusion in plague; 'the precipitation of the whole poem [is] towards the plague in Athens, the inclination of the text, the fall of atoms and the cataract of letters' (Serres, 69). In so doing he reveals the potential tragedy latent within his aetiology. Likewise, Shakespeare's tragedy turns comedic interrelation to contamination, interaction to transmission. The traversing atom becomes infectious carrier, the hospitable receptivity of porous bodies renders them receptive to hostile invasion - these are the 'pernicious principles of contagion and epidemic' (Serres, 89) - and the communication of the kind couple becomes the communication of sympathetic disease:

\footnotetext{
32 Here my discussion coincides with that of Terence Cave: 'the comedies and romances compose a complex structure of confusion - narrative, figurative, cognitive - in precisely the terms necessary for a final inversion delivering the maximum sense of coherence and rectification' (286). Cave's sense of formborn-of-confusion explains a number of other intersections: the productivity of paralogism (formative misreading) correlates to my advocation of a readerly swerve; his description of how 'chance is fruitful, leading to new - though often disturbing - ways of reading old relations' (278) correlates with my Lucretian-influenced description of narrative restructuring and the predication of causal congruity upon accidental event; and his description of how anagnorisis (the moment of recognition) evolves from the 'coming together of fragments of action which had been either arbitrarily separated or connected by equally arbitrary misunderstanding [that occurs as if by] chance' (278) has Lucretian as well as Aristotelian resonance. Recognitions: A Study in Poetics (Oxford: Clarendon Press, 1988).
} 
$[\mathrm{My}]$ weakness, married to thy stronger state,

Makes me with thy strength to communicate.

If aught possess thee from me, it is dross,

Usurping ivy, briar, or idle moss,

Who, all for want of pruning, with intrusion

Infect thy sap, and live on thy confusion.

II. ii. $165-70$

While, in Shakespeare's Comedy, Adriana's commitment to marriage is predicated on this sense of indivisible cross-contamination, both Lucretius' atomist poem and Shakespeare's tragic vision will realise the previously implicit poisonous potential of interactive identities that lay latent in the comedic celebration of indivisibility: 'Even so quickly may one catch the plague? / Methinks I feel this youth's perfections / With an invisible and subtle stealth / To creep in at my eyes' (TN. I. v. 250-3). Once 'no man is the lord of anything, ... / Till he communicates his parts to others' (Tro. III. iii. 115-17, emphasis added), communion with an other risks the communication of contagion, until each 'friend ... bear[s] his friend's infirmities' ('bear' connoting both 'put up with' and 'carry' [JC. IV. iii. 86]). Reread then, with trepidation, Serres's summary of atomic interaction; 'nature [is] an ensemble of linked things, not an incoherent or chaotic ensemble of objects but a communicating ensemble' (94). Because once we see the tragic implications of subjective interdependence, the lively interactions of the atoms are revealed to be deadly infections - 'Our Bodies Constitutions agree / With the malicious ayre and so contract / The quicke Infection' - and the kind contacts of character-to-character threaten the contraction and transmission of plague: 'contagion', as in Thomas Lodge's description of the plague, being 'no other thing but a like disposition by a certaine hidden consent communicated by touch vnto another'. ${ }^{33}$

The atheism of Lucretius provides no conciliatory support (there is nothing to de-pend on/from), but neither does dependency on the other. ${ }^{34}$ While comic resolution reveals a causality that denies chance, tragedy does not refute causality, it simply refuses to find comfort or coherence in it. The transmission from cause to effect is revealed as that of infector to infected.

Interconnection becomes a prerequisite for comic in-dividuality, but is potentially lethal in tragedy: what gave identity, now takes it away; infection infects interaction; communication communicates. This is a tragic lesson learnt in plagued Athens:

All things are transmitters as the plague hangs in the pendulous air, we are plunged into the space of communication with those who look black. upon us, strike us with their tongues, we bathe (although it is a naughty night to swim in) in an interlacing of channels where duplicitous messengers transmit saucy posts, plunged into the ... fluencies [of atomic fluxion] as the fretful elements, the to-and-fro-conflicting winds and rain blast us, beaten into clamorous whining, struck with heart-strook injuries, wounded by a father's piercing curse, sometimes ravaged till man's nature cannot carry the affliction, burned till our white hairs singe, painful. O, how this mother swells up toward my heart! Thus there is no defence against sickness. Sick, O, sick! Everything flows and illness courses. My sickness grows upon me. It insinuates itself like rain that invades us to the skin, and the plague that runs in our corrupted blood.

${ }^{33}$ Abraham Holland, 'London, Look-backe', in J. D., Salomons Pest-House; or, Towre-Royall (London, 1630), pp. 56-69, 59; Thomas Lodge, A Treatise of the Plague (London, 1603), L2r.

${ }^{34}$ Clearly, my Lucretian reading sits uncomfortably alongside "redemptive" theologised readings of the Comedy: see Bishop; James L. Sanderson, "Patience in The Comedy of Errors', Texas Studies in Literature and Language 16 (1974-5), 603-18; and Patricia Parker on its 'New Testamental recognition scene' (327), 'Elder and younger: the opening scene of The Comedy of Errors,' Shakespeare Quarterly 34 (1983), 325-7. 
The clinamen's lightning - the 'sulph'rous and thought-executing fires, / Vaunt-couriers of oakcleaving thunderbolts' (III. ii. 4-5) - strikes across the 'perpendicular... f[a]ll' (IV. vi. 54) but does not initiate order or generate structure. 'Let me talk with this philosopher': perhaps Lucretius' atomic philosophy could tell Lear 'the cause of thunder' (III. iv. 154-5), and the cause of plague, but there may not be a 'cause in nature that makes these hard hearts' (III. vi. 77-8), or that causes this unnatural unkindness. 'Tis the time's plague' (IV. i. 46) when this is The Nature of Things.

35 III. iv. 67; II. iv. 160; III. iv. 110-11; II. iv. 41; III. i. 4-11; II. ii. 23; III. i. 17; I. iv. 300; III. ii. 48-9; 6; II. iv. 56-7; V. iii. 95; 105; II. iv. 224-5; III. iv. 7. 